\title{
Review
}

Peng Xiao*, Hongmei Li*, Xianjiang Li and Dewei Song

\section{Analytical barriers in clinical B-type natriuretic peptide measurement and the promising analytical methods based on mass spectrometry technology}

https://doi.org/10.1515/cclm-2018-0956

Received August 31, 2018; accepted October 22, 2018; previously published online November 24, 2018

Abstract: B-type natriuretic peptide (BNP) is a circulating biomarker that is mainly applied in heart failure (HF) diagnosis and to monitor disease progression. Because some identical amino acid sequences occur in the precursor and metabolites of BNP, undesirable cross-reactions are common in immunoassays. This review first summarizes current analytical methods, such as immunoassay- and mass spectrometry (MS)-based approaches, including the accuracy of measurement and the inconsistency of the results. Second, the review presents some promising approaches to resolve the current barriers in clinical BNP measurement, such as how to decrease cross-reactions and increase the measurement consistency. Specific approaches include research on novel BNP assays with higher-specificity chemical antibodies, the development of International System of Units (SI)-traceable reference materials, and the development of structure characterization methods based on state-of-the-art ambient and ion mobility MS technologies. The factors that could affect MS analysis are also discussed, such as biological sample cleanup and peptide ionization efficiency. The purpose of this review is to explore and identify the main problems in BNP clinical measurement and to present three types of approaches to resolve these problems, namely, materials, methods and instruments. Although novel approaches are proposed here, in practice, it is worth noting that the BNP-related peptides including unprocessed proBNP were all measured in clinical BNP

\footnotetext{
*Corresponding authors: Peng Xiao and Hongmei Li, Division of Chemical Metrology and Analytical Science, National Institute of Metrology, Beijing 100029, P.R. China, Phone: +86-10-64228896, Fax: +86-10-64271639, E-mail: xiaop@nim.ac.cn (P. Xiao); lihm@nim.ac.cn (H. Li)

Xianjiang Li and Dewei Song: Division of Chemical Metrology and Analytical Science, National Institute of Metrology, Beijing, P.R. China
}

assays. Therefore, approaches that aimed to measure a specific BNP or proBNP might be an effective way for the standardization of a particular BNP form measurement, instead of the standardization of "total" immunoreactive BNP assays in clinical at present.

Keywords: B-type natriuretic peptide; clinical measurement; cross-reactivity; immunoassay; mass spectrometry; reference material.

\section{Introduction}

B-type natriuretic peptide (BNP) is a member of the natriuretic peptide (NP) family [1, 2]. As an indicator for myocardial function evaluation, BNP has been applied in the clinical diagnosis of heart failure (HF) and acute myocardial infarction and in monitoring disease progression [3-5]. In addition, drugs designed based on the amino acid structure and physiological mechanism of BNP have been proven to effectively relieve and even treat HF disease [6-8]. BNP precursor and related peptides are also relevant for HF evaluation [9]. The formation of the peptide is presented in Figure 1 [10]. The European Society of Cardiology (ESC) defined the upper limit of normal in the non-acute setting as $125 \mathrm{ng} / \mathrm{L}$ BNP and $35 \mathrm{ng} / \mathrm{L}$ NT-proBNP [11]. However, in infants, the concentrations of BNP and NT-proBNP are partly dependent on age and sex $[12,13]$.

The accurate measurement of NPs is no doubt the most significant event for patient diagnosis and treatment. However, the results of current clinical measurement are sometimes confusing. For instance, the BNP concentration of HF patients under the New York Heart Association classification IV (NYHA-IV) is defined as higher than $290 \mathrm{fmol} / \mathrm{mL}(\approx 1004 \mathrm{ng} / \mathrm{L})$. Surprisingly, however, Hawkridge et al. [14] found very little BNP when using Fourier transform ion cyclotron resonance mass spectrometry (FT-ICR MS). Similarly, Niederkofler et al. [15] found a BNP range from 900 to $5000 \mathrm{ng} / \mathrm{L}$ by Biosite 


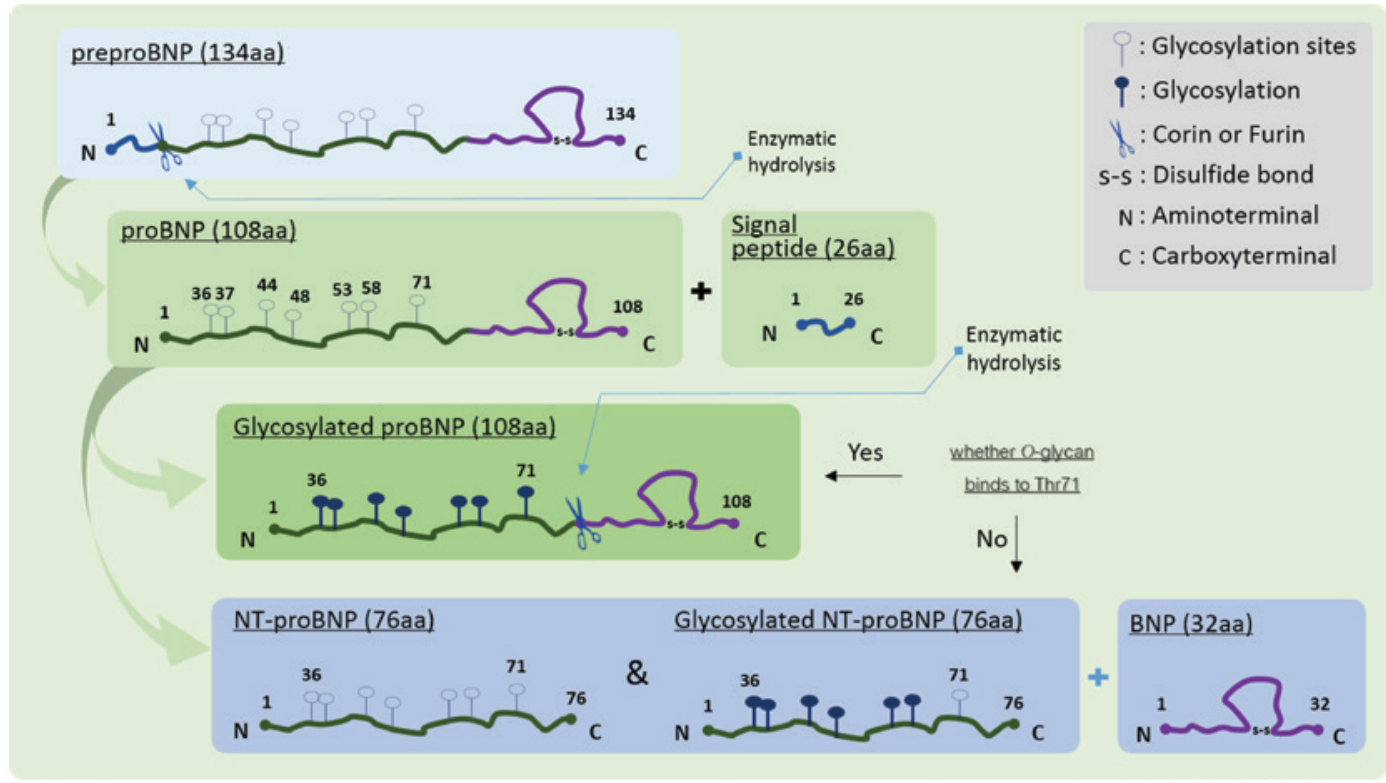

Figure 1: Formation scheme of proBNP, NT-proBNP and BNP.

assay, but parallel measurements based on the MS method indicated an intact BNP concentration of only $25-43 \mathrm{ng} / \mathrm{L}$ in the circulation of HF patients. Miller et al. [16] developed a quantitative MS method for BNP metabolites and corin enzyme. The results of the Beckman assay and the developed MS approach exhibited poor correlation. These studies suggested that the results measured by immunoassays and MS approaches were quite different. In addition, for immunoassays, deviation was observed between different platforms [17]. Saenger et al. [18] investigated five prevailing BNP immunoassay platforms and found that all assays exhibited substantial cross-reactivity with the proBNP peptide. In addition, from 2005 to 2011, more than 100 Italian laboratories participated in a BNP proficiency testing program, and the statistical data showed a $43.0 \%$ coefficient of variation in the BNP immunoassay [19]. Franzini et al. [20] investigated the systematic differences between a new commercial method (ST-AIA-PACK in brief) and the Triage Biosite assay (a routine method used in reference laboratories) and found a $46.9 \%$ mean bias between them. Other similar cases were also reported in remarkable reviews [21-23]. More recently, Vasile and Jaffe [24] examined the analytical characteristics of the seven most popular commercial BNP immunoassays and discussed the inherent problems.

The poor harmonization in BNP testing was caused by many factors, such as heterogeneity in the analytical methods, systematic error in immunoassays and quality attributes of the diagnostic reagents. Because BNP standardization has not been carried out or is still in the early stages worldwide, it has been difficult to elucidate the problem until now [25]. However, cross-reaction is an undisputed clinical problem [17, 18, 26, 27]. To explore these problems, this review proposes new materials and methods, including the development of International System of Units (SI)-traceable reference materials and reagents and the exploration of novel MS analytical methods.

\section{BNP structure}

\section{Formation of BNP}

The overloading of volume and pressure in the heart causes cardiac wall tension and stretching, volume overload, or ischemia, resulting in the increased production and release of NPs. After NPs are expressed and released, the precursor of proBNP is digested by enzymes such as corin and furin in circulation, generating equimolar amounts of the amino-terminal and carboxyterminal products, commonly referred to as NT-proBNP and BNP $[21,22,28]$. Consequently, such peptides normally coexist in circulation [29], which foreshadows questions in BNP clinical measurement.

\section{Metabolism and forms of BNP}

BNP has a ring structure formed by cysteines. Previous studies have shown that BNP bioactivity is lost after ring structure disruption, which is commonly mediated by neutral endopeptidases in circulation [22]. This structure 
plays a vital role in natriuretic peptide receptor (NPR) recognition [30]. The combination of BNP and NPR-A could enhance the cyclic guanosine monophosphate (cGMP) pathway, leading to a series of physiological responses $[31,32]$. NPR-C plays a role in BNP clearance. He et al. [30] determined the crystal structure of the BNP/NPR-C complex.

In circulation, enzymes such as neprilysin, dipeptidyl peptidase IV (DPP-IV), insulin degrading enzyme and meprin will hydrolyze BNP at specific amino acids, generating truncated BNPs such as BNP 3-32, BNP 4-32 and BNP $5-32[29,33,34]$. After enzymatic reactions, the immunological activity of BNP would be altered or even lost [22, 35], which is the reason the half-life of BNP in plasma is only approximately $22 \mathrm{~min}$ long [36]. Obviously, the inhibition of these enzymes could maintain BNP bioactivity [8]. Non-bioactive NT-proBNP exhibited better stability and could exist in plasma for approximately 7 days at room temperature [37]. In contrast to proBNP, BNP is not modified by glycosylation [38]. Seferian et al. [39] raised antibodies against a variety of forms of BNP and found that no posttranslational modification of these peptides occurred.

Because BNP and its metabolites might reflect different cardiac diseases or different degrees of myocardial injury, scientists seek to evaluate their bioactivity individually. Therefore, the development of biological methods is feasible but not sufficient. Chemical methods, such as chromatographic and mass spectrometric approaches, are effective for structure and quantity analysis. Therefore, the combination of biological and chemical approaches is a robust approach to such in-depth research.

\section{BNP measurement}

To date, a variety of immune platforms and point-ofcare testing products have been adopted for clinical BNP measurements. In addition, chromatographically assisted MS analytical methods such as high performance liquid chromatography coupled MS or capillary electrophoresis coupled MS (CE-MS) are emerging as reliable tools for the qualitative and quantitative measurement of BNP.

\section{Clinical BNP assays}

Worldwide, in vitro diagnostic (IVD) reagents and immunoassays have dominated the clinical testing laboratories.
Because Access (Beckman Coulter) and Triage (Alere) did not characterize capture or detect epitopes, only five tests were performed here. The data in Table 1 and Figure 2 are from the IFCC website (http://www.ifcc.org/media/102208/ NP\%20Assay\%20Table\%20C\%20SMCD\%20vJuly_2011. pdf) and the reviews of Maalouf and Bailey [23] and Vasile and Jaffe [24]. Commercial assays are sandwich-type assays based on two monoclonal antibodies or a combination of monoclonal and polyclonal antibodies [40]. BNP 3-32, BNP 4-32, BNP 5-32 and even proBNP are also targets during BNP 1-32 assays.

\section{Cross-reactivity of BNP}

Before discussing cross-reaction, whether truncated BNPs and/or proBNP is the main form in HF patients is an important issue that needs to be investigated. Some studies have focused on this question and provided clear evidence. For instance, according to western blot results using antibodies directed against BNP, Liang et al. [41] reported that proBNP is a major form of immunoreactive BNP in $\mathrm{HF}$ plasma, which is similar to the results of Seferian et al. [39]. For bioactivity analysis, one approach is to measure the second messenger cGMP, which was generated after NPR recognition [29]. Based on this approach, Heublein et al. [42] showed that the stimulation of cGMP production by the DPP-IV product BNP 3-32 is similar to that of BNP 1-32 when tested on human cardiac fibroblasts or cardiomyocytes. Recently, by using immunocapture-assisted time-of-flight MS (TOF MS), Suzuki et al. [43] found that BNP 5-32 presented prognostic ability in HF patients. In addition, BNP 432, BNP 1-25, BNP 1-26 and even BNP 5-31 also retained bioactivity, giving cGMP responses similar to that of BNP 1-32 [15, 29]. Therefore, one explanation for the findings of Adam and Eric is that the immunoassay results reflect the proBNP or truncated BNP concentrations instead of BNP 1-32, and the MS measurement results proved that only a small amount of BNP 1-32 existed in the sample $[14,15]$.

To eliminate cross-reactions with proBNP, Lewis et al. [17] designed a new polyclonal antibody that could recognize the amino-terminal sequence of BNP. The combination of homemade antibody and 50E1 was used in the BNP 1-32 immunoassay. Because such a combination could recognize both the amino- and the carboxyterminal of BNP $1-32$, it would provide improved accuracy. As expected, compared with the combination of $24 \mathrm{C} 5$ and 50E1, the new method reduces cross-reactions with proBNP and truncated BNPs effectively at a concentration level of $5 \mathrm{nmol} / \mathrm{L}$ $\left(\approx 1.73 \times 10^{4} \mathrm{ng} / \mathrm{L}\right)$, especially for BNP 3-32 and BNP 7-32 [17]. 
Table 1: Analytical characteristics of commercial BNP Assays as per the manufacturer.

\begin{tabular}{|c|c|c|c|c|}
\hline Assay & Capture antibody & Detection antibody & Standard material & FDA cleared yes/no/claim \\
\hline $\begin{array}{l}\text { Abbott } \\
\text { Architect, AxSYM } \\
\text { iSTAT }\end{array}$ & $\begin{array}{l}\mathrm{NH} 2 \text { terminus and part of } \\
\text { the ring structure (Scios), } \\
\text { murine monoclonal } \mathrm{Ab} \text {, aa } \\
5-13\end{array}$ & $\begin{array}{l}\mathrm{COOH} \text { terminus, murine } \\
\text { monoclonal } \mathrm{Ab}, \mathrm{aa} \\
26-32\end{array}$ & Synthetic BNP 1-32 & $\begin{array}{l}\text { Assist in diagnosis of HF; assess } \\
\text { severity of disease }\end{array}$ \\
\hline $\begin{array}{l}\text { Alere } \\
\text { Triage BNP }\end{array}$ & $\begin{array}{l}\mathrm{NH} 2 \text { terminus and part of } \\
\text { the ring structure (Scios), } \\
\text { murine monoclonal } \mathrm{Ab} \text {, aa } \\
5-13\end{array}$ & $\begin{array}{l}\text { BNP (Biosite), murine } \\
\text { omniclonal AB, epitope } \\
\text { not characterized }\end{array}$ & Recombinant BNP & $\begin{array}{l}\text { Aid in diagnosis and severity } \\
\text { assessment of HF; risk } \\
\text { stratification of patients with ACS } \\
\text { and HF; } \\
\text { FDA cleared }\end{array}$ \\
\hline $\begin{array}{l}\text { Beckman Coulter } \\
\text { Access, Access 2, DxL }\end{array}$ & $\begin{array}{l}\text { BNP (Biosite), murine } \\
\text { omniclonal } A B \text {, epitope not } \\
\text { characterized }\end{array}$ & $\begin{array}{l}\mathrm{NH} 2 \text { terminus and part } \\
\text { of the ring structure } \\
\text { (Scios), murine } \\
\text { monoclonal Ab, aa } 5-13\end{array}$ & Recombinant BNP & $\begin{array}{l}\text { Diagnosis HF; assess severity HF; } \\
\text { risk ACS; risk HF }\end{array}$ \\
\hline $\begin{array}{l}\text { Siemens (Bayer) } \\
\text { ACS 180, Advia Centaur, } \\
\text { Advia Centaur CP }\end{array}$ & $\begin{array}{l}\mathrm{COOH} \text { terminus (BC- } \\
\text { 203) (Shionogi), murine } \\
\text { monoclonal } \mathrm{AB} \text {, aa } 27-32\end{array}$ & $\begin{array}{l}\text { Ring structure } \\
\text { (KY-hBNPII) (Shionogi), } \\
\text { murine monoclonal AB }\end{array}$ & Synthetic BNP & $\begin{array}{l}\text { Aid in diagnosis and assessment } \\
\text { of severity of HF; predict survival } \\
\text { and likelihood of future HF in ACS } \\
\text { patients }\end{array}$ \\
\hline $\begin{array}{l}\text { Siemens (Dade Behring) } \\
\text { Dimension VISTA, } \\
\text { Dimension ExL }\end{array}$ & $\begin{array}{l}\text { Ring structure (KY-hBNPII) } \\
\text { murine monoclonal AB, aa } \\
14-21\end{array}$ & $\begin{array}{l}\mathrm{COOH} \text { terminus } \\
\text { (BC-203), murine } \\
\text { monoclonal } \mathrm{AB} \text {, aa } \\
27-32\end{array}$ & Synthetic BNP 32 & $\begin{array}{l}\text { Aid in diagnosis and assessment } \\
\text { of severity of HF; predict survival } \\
\text { and likelihood of future HF in ACS } \\
\text { patients; pending FDA clearance }\end{array}$ \\
\hline Shionogi & $\begin{array}{l}\mathrm{COOH} \text { terminus }(\mathrm{BC}-203) \text {, } \\
\text { murine monoclonal } \mathrm{AB}, \mathrm{aa} \\
27-32\end{array}$ & $\begin{array}{l}\text { Ring structure } \\
\text { (KY-hBNPII), murine } \\
\text { monoclonal AB }\end{array}$ & Synthetic BNP & Not FDA cleared \\
\hline $\begin{array}{l}\text { Tosoh } \\
\text { AIA-2000, } \\
\text { ST-AIA-PACK }\end{array}$ & $\begin{array}{l}\mathrm{COOH} \text { terminus (BC- } \\
203)(\text { Shionogi), murine } \\
\text { monoclonal } \mathrm{AB} \text {, aa } 27-32 \\
{[21]}\end{array}$ & $\begin{array}{l}\text { Ring structure } \\
\text { (KY-hBNPII) (Shionogi), } \\
\text { murine monoclonal AB } \\
{[21]}\end{array}$ & Synthetic BNP [21] & Not FDA cleared \\
\hline
\end{tabular}

Source: http://www.ifcc.org/media/102208/NP\%20Assay\%20Table\%20C\%20SMCD\%20vJuly_2011.pdf

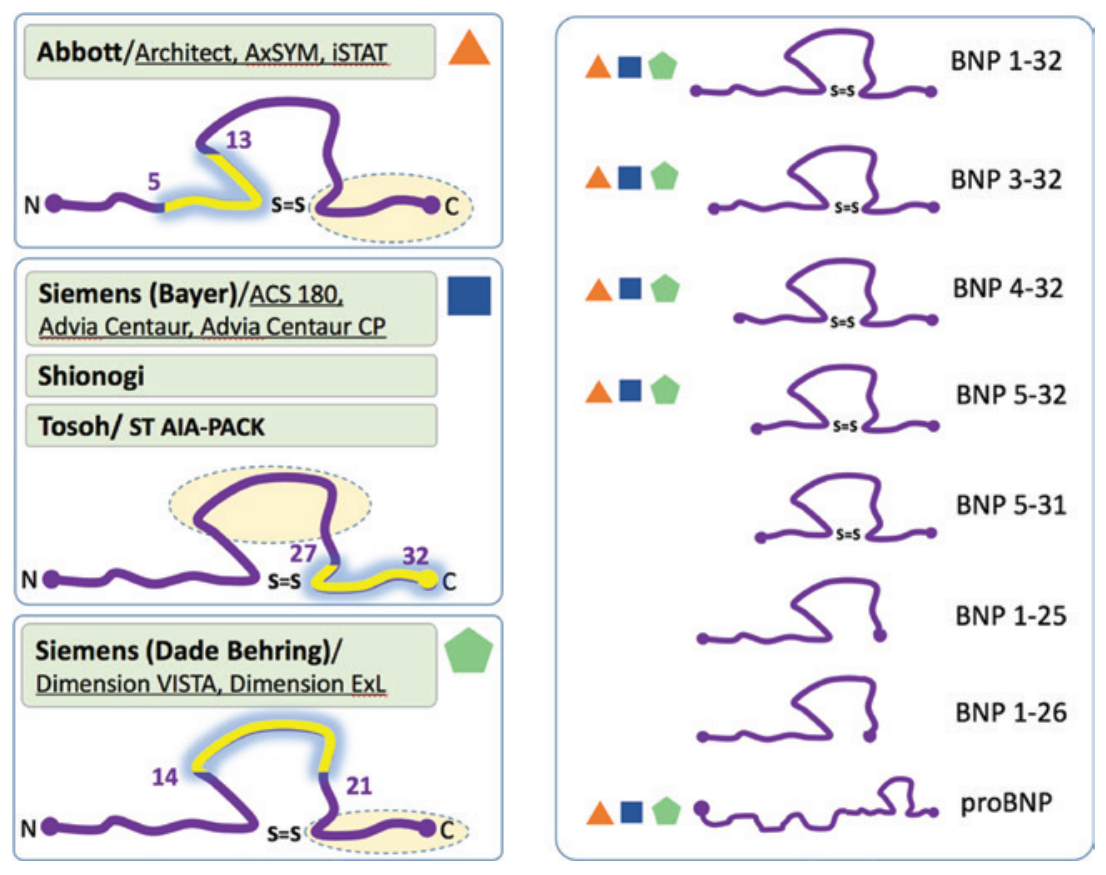

Figure 2: Epitopes captured by different commercial BNP immunoassays in the world (left) and the main forms of BNP metabolites (right). The yellow lines and cycles on BNP represent the sequences that recognized by each capture and detect antibody, respectively. Triangle, square and pentagon represent different kinds of assay platforms. 
These results are attractive, but the most current studies highlighted that the clinical BNP immunoassays in current use are far from complete.

Because BNP metabolites and proBNP are partly representative of BNP 1-32 in immunoassays, another solution for clinical use is to separate them before the assay. However, the separation of similarly structured NPs is complicated and time consuming, which does not meet the needs of clinical testing. Therefore, it seems that the development of a higher-specificity antibody is a more realistic and promising approach, similar to the encouraging work of Lewis et al. [17].

\section{MS analytical methods}

The MS platform generally includes separation devices, such as liquid chromatography (LC), ion exchange chromatography or capillary electrophoresis (CE) instruments. The superior resolution and accuracy of MS are provided by a mass analyzer. MS can provide an in-depth view of similar peptides because it can measure their mass-tocharge ratios $(\mathrm{m} / \mathrm{z})$. In combination with a high-resolution mass analyzer, such as TOF, Orbitrap or FT-ICR, the amino acids can be sequenced by the application of a matching algorithm to their fragment ions.

Because the abundant proteins in serum and plasma could inhibit MS intensity, cleanup is always a necessary operation. Solid-phase extraction (SPE) is the conventional cleanup method. Commercial SPE products can exclude albumin, IgG and IgA efficiently. Moreover, if any specific affinitive ligands are introduced on the SPE material, such as antibody-coupled beads or matrix, the resulting online chromatographic analysis is more sensitive [14].

As shown in Table 2, various platforms have been used to investigate the metabolic mechanism and the structure of intact BNP or truncated BNPs from patients. In practice, an additional offline cleanup procedure was adopted when using matrix-assisted laser desorption ionization (MALDI). Online LC or CE separation methods are commonly adopted in electrospray ionization sources (ESIs). The structural information obtained from MS methods is usually the key evidence to support and verify the hypothesis of the authors, and corresponding information is unavailable from the immunoassay approach [43]. For instance, the signal peptide discussed in the work of Siriwardena et al. [44] was derived from pre-proBNP, although it does not belong to the BNP family. This approach provides a reference for further BNP studies. Fujimoto et al. [47] developed an immunocapture-assisted MALDI-TOF MS method to investigate whether truncated BNP could be indicative of ischemic heart disease, and they found that BNP 5-32 may reflect the pathophysiological process involved in restenosis.

Compared with identification studies performed by MS, quantitative MS studies are usually complicated. The cleanup recovery, quantitative range, limit of quantitation, method accuracy, precision and repeatability need to be investigated. According to the research purpose, samples could be analyzed on the intact, enzymatic peptide and/ or amino acid level. Intact analysis is rapid, requires less sample pretreatment and is compatible with online operation; however, the intact standard is difficult to obtain. Peptide and amino acid analysis are more complex, but reference peptides or reference amino acids are easy to obtain. In addition, stable isotope-labeled peptides or amino acids are suitable for the evaluation of cleanup efficiency and even for absolute quantification. Parameters such as quantitative range, limit of quantitation, method precision and repeatability are closely related to the MS analyzer type and settings. Quantification accuracy is usually dependent on the quality and uncertainty of internal and external standards. Torma et al. [25] developed a method of SI-traceable quantification for reference material preparation. During this work, synthetic BNP was quantified at the amino acid and peptide levels, which were obtained from hydrolyzed by hydrochloric acid or enzymatically digested by trypsin. In addition, peptides labeled with heavy isotopic carbon atoms and nitrogen atoms were quantified based on the SI-traceable amino acids and then adopted as the internal standard. Each approach in Table 3 is designed to reduce matrix complexity before quantification, and immune purification and LC methods have become standard operations.

\section{A summary of the immunoassay and MS analytical methods}

MS-based methods are widely adopted in discovery research and are suitable for obtaining more accurate prediction and HF diagnosis [52]. Although chromatographic approaches are time consuming and high in cost, the results are usually in depth and reliable [53]. Therefore, such methods are more promising for BNP structure and activity investigation than for clinical application unless analytical cost reduction and efficiency improvement are realized. In clinical use, microbial identification by MALDITOF and neonatal disease screening are best examples to date [54]. LC-MS and CE-MS approaches have become much more robust and convenient than before, but there is room for considerable further progress. At present, the 
Table 2: MS-based analytical methods applied for BNP identification.

\begin{tabular}{|c|c|c|c|c|c|c|}
\hline Approaches & Platform & Sample & Separation strategy & Detection range & Summary & Ref. \\
\hline ESI-QTOF & Agilent & $\begin{array}{l}\text { Commercial } \\
\text { synthetic BNP } \\
\text { (purity) }\end{array}$ & 1. LC & Not stated & $\begin{array}{l}\text { Major impurities } \\
\text { identification by using } \\
\text { high-resolution MS }\end{array}$ & [25] \\
\hline ESI-Ion trap & Bruker & Synthetic BNP & $\mathrm{n} / \mathrm{a}$ & $\approx 17-346 \mathrm{ng} / \mathrm{L}$ & $\begin{array}{l}\text { Dynamic characterization } \\
\text { of BNP 1-32 products } \\
\text { which were hydrolyzed by } \\
\text { DPP-IV }\end{array}$ & [34] \\
\hline ESI-LTQ Orbitrap & Thermo & $\begin{array}{l}\text { Synthetic BNP } \\
17-26\end{array}$ & $\begin{array}{l}\text { 1. C18 SPE; } 2 \text {. } \\
\text { Immunopurified; } 3 \text {. LC } \\
\text { (size exclusion) }\end{array}$ & $\begin{array}{l}0-640 \mathrm{pmol} / \mathrm{L} \\
(\approx 0-621 \mathrm{ng} / \mathrm{L})\end{array}$ & $\begin{array}{l}\text { Confirmation of modified } \\
\text { BNP } 17-26 \text { based on its } \\
\text { multistage ions }\left(\mathrm{MS}^{3}\right)\end{array}$ & [44] \\
\hline ESI-LTQ FT & Thermo & $\begin{array}{l}\text { Commercial } \\
\text { synthetic BNP } \\
\text { and its enzymatic } \\
\text { peptides (purity) }\end{array}$ & 1. Multidimensional LC & $2.5 \times 10^{5} \mathrm{ng} / \mathrm{L}$ & $\begin{array}{l}\text { Optimization of LC and MS } \\
\text { conditions to develop a } \\
\text { high sensitivity detection } \\
\text { method }\end{array}$ & [45] \\
\hline \multirow[t]{6}{*}{ MALIDI-TOF } & $\begin{array}{l}\text { Applied } \\
\text { Biosystems }\end{array}$ & $\begin{array}{l}\text { Endogenous human } \\
\text { BNP } 17-26\end{array}$ & $\begin{array}{l}\text { 1. C18 SPE; } 2 \text {. } \\
\text { immunopurified }\end{array}$ & $\begin{array}{l}0-640 \mathrm{pmol} / \mathrm{L} \\
(\approx 0-621 \mathrm{ng} / \mathrm{L})\end{array}$ & $\begin{array}{l}\text { Sequence analysis of } \\
\text { endogenous BNP 17-26, } \\
\text { which was enriched by } \\
\text { homemade antiserum }\end{array}$ & [44] \\
\hline & $\begin{array}{l}\text { PerSeptive } \\
\text { Biosystems }\end{array}$ & $\begin{array}{l}\text { Rainbow trout } \\
\text { vasculature }\end{array}$ & $\begin{array}{l}\text { 1. C18 SPE; 2. SDS- } \\
\text { PAGE }\end{array}$ & Not stated & $\begin{array}{l}\text { Research of functional } \\
\text { similarities between } \\
\text { teleost and mammalian NP } \\
\text { systems }\end{array}$ & [46] \\
\hline & Bruker Autoflex & $\begin{array}{l}\text { Plasma from NYHA- } \\
\text { III and IV patients }\end{array}$ & $\begin{array}{l}\text { 1. Antibody-derivatized } \\
\text { affinity pipettes }\end{array}$ & $25-43 \mathrm{ng} / \mathrm{L}$ & $\begin{array}{l}\text { Distinguished and } \\
\text { detection of BNP 1-32 } \\
\text { and BNP metabolites } \\
\text { simultaneously }\end{array}$ & [15] \\
\hline & Bruker Autoflex & $\begin{array}{l}\text { Plasma from NYHA-I } \\
\text { to IV patients }\end{array}$ & $\begin{array}{l}\text { 1. Antibody-derivatized } \\
\text { affinity pipettes }\end{array}$ & $\begin{array}{l}\approx 0-250 \mathrm{ng} / \mathrm{L} \text { for } \\
\text { BNP } 1-32\end{array}$ & $\begin{array}{l}\text { Cross-reaction of proBNP } \\
\text { was happened in BNP 1-32 } \\
\text { clinical measurement }\end{array}$ & [16] \\
\hline & $\begin{array}{l}\text { Axima CFR/ } \\
\text { Confidence }\end{array}$ & $\begin{array}{l}\text { Plasma from } \\
\text { ischemic heart } \\
\text { disease patients }\end{array}$ & 1. Immunopurified & $20-3000 \mathrm{ng} / \mathrm{L}$ & $\begin{array}{l}\text { The truncated BNP, such } \\
\text { as BNP 5-32, may reflect } \\
\text { pathophysiological } \\
\text { process involved in } \\
\text { restenosis }\end{array}$ & [47] \\
\hline & $\begin{array}{l}\text { Axima } \\
\text { Confidence }\end{array}$ & $\begin{array}{l}\text { Plasma from acute } \\
\text { HF patients }\end{array}$ & 1. Immunopurified & Not stated & $\begin{array}{l}\text { BNP 5-32 presented the } \\
\text { prognostic ability in HF } \\
\text { patients }\end{array}$ & [43] \\
\hline
\end{tabular}

development of a plasma BNP reference material using MS methods for use in immunoassays would be a comprehensive solution to harmonize the clinical results.

In immunoassays, antibodies are used for quantitation. Because BNP immunoassays commonly have poor specificity and the results cannot be traced to SI units, the immunoassay results are questionable. However, in MS methods, antibodies are tools used for biological sample cleanup; furthermore, the quantitative results are dependent on the standards spiked at the beginning. Thus, the quantitative results from MS-based methods are more reliable and accurate. These properties are summarized in Table 4. Clearly, immunoassays are low in cost and highly efficient. After all, for severe HF patients, time is life.

\section{Improvement of BNP clinical testing}

For improved testing, cross-reaction and lack of standardization should be resolved as soon as possible. Here, for the purpose of reducing negative effects on BNP measurement, some suggestions related to materials, methods and analytical devices have been discussed and examined.

\section{Reference material}

According to the guidelines of ISO 17511, in a clinical testing laboratory, the calibrator, which is also referred to as standard material or reference material, is an essential 
Table 3: MS-based analytical methods applied for BNP quantification.

\begin{tabular}{|c|c|c|c|c|c|c|}
\hline Approaches & Platform & Sample & Separation strategy & Detection range & Efficiency & Ref. \\
\hline \multirow[t]{5}{*}{ LC-tripleQ } & Agilent & $\begin{array}{l}\text { Commercial synthetic } \\
\text { BNP (purity) }\end{array}$ & $\begin{array}{l}\text { 1. Online desalting and } \\
\text { chromatographic separation }\end{array}$ & $52-520 \mathrm{pg} / \mathrm{g}$ & $\begin{array}{l}20 \text { min } \\
\text { gradient/ }\end{array}$ & [25] \\
\hline & Agilent & Human plasma & 1. Protein precipitation; & & LC run & \\
\hline & & & 2. SPE; & & & \\
\hline & & & 3. LC & & & \\
\hline & Waters & $\begin{array}{l}\text { Commercial BNP 1-32 } \\
\text { added human plasma }\end{array}$ & $\begin{array}{l}\text { 1. Purification by using antibody } \\
\text { coupled magnetic beads; } \\
\text { 2. LC }\end{array}$ & $2.42-90 \mathrm{ng} / \mathrm{L}(\mathrm{BNP} 1-32)$ & $8 \mathrm{~min} / \mathrm{run}$ & [48] \\
\hline \multirow[t]{2}{*}{ LC-LTQ } & Thermo & $\begin{array}{l}\text { Commercial purified } \\
\text { BNP (purity) }\end{array}$ & 1. LC & $1732-433 \times 10^{3} \mathrm{ng} / \mathrm{L}$ & $5 \mathrm{~min} / \mathrm{run}$ & [49] \\
\hline & Thermo & $\begin{array}{l}\text { Commercial BNP } \\
\text { added human plasma }\end{array}$ & $\begin{array}{l}\text { 1. Guanidine denaturation; } \\
\text { 2. protein precipitation; } \\
\text { 3. ultrafiltration; } \\
\text { 4. LC }\end{array}$ & $\begin{array}{l}866 \mathrm{ng} / \mathrm{L} \text { (limit of } \\
\text { detection) }\end{array}$ & $30 \mathrm{~min} / \mathrm{run}$ & [49] \\
\hline \multirow[t]{2}{*}{ LC-FT ICR } & IonSpec & $\begin{array}{l}\text { Plasma from NYHA-IV } \\
\text { patients }\end{array}$ & $\begin{array}{l}\text { 1. Offline C8 SPE; } \\
\text { 2. IP purification; } \\
\text { 3. NanoLC }\end{array}$ & $\begin{array}{l}\approx 15 \mathrm{fmol}(\approx 0.05 \mathrm{ng}) \\
\text { on column (limit of } \\
\text { detection) }\end{array}$ & $\begin{array}{l}50 \text { min } \\
\text { gradient/ } \\
\text { LC run }\end{array}$ & [14] \\
\hline & Thermo & Synthetic BNP (purity) & 1. Online desalting & $\begin{array}{l}0.357-1.26 \mathrm{fmol} \\
(\approx 1.2-4.4 \mathrm{ng}) \text { on column } \\
\text { (limit of detection) }\end{array}$ & $14 \mathrm{~min} / \mathrm{run}$ & [50] \\
\hline CE-Q Orbitrap & Thermo & Human plasma & $\begin{array}{l}\text { 1. Centrifugation; } \\
\text { 2. CESI } 8000 \text { high-performance } \\
\text { separation module; } \\
\text { 3. CE }\end{array}$ & $(50-250) \times 10^{6} \mathrm{ng} / \mathrm{L}$ & $16 \mathrm{~min} / \mathrm{run}$ & [51] \\
\hline
\end{tabular}

Table 4: Major properties of MS-based analytical method vs. immunoassay for BNP measurement.

\begin{tabular}{|c|c|c|}
\hline & MS-based analytical methods & Immunoassays \\
\hline $\begin{array}{l}\text { Major steps for biological sample } \\
\text { pretreatment }\end{array}$ & $\begin{array}{l}\text { Commonly multisteps, including SPE, antibody- } \\
\text { assisted purification and LC separation }\end{array}$ & Mainly centrifuge separation \\
\hline Sample volume & $\begin{array}{l}\text { Depends on recovery efficiency of BNP, MS } \\
\text { detector type and scan mode, commonly ranged } \\
\text { from hundreds of microliters to a few milliliters } \\
\text { of plasma }\end{array}$ & $\begin{array}{l}\text { Usually dozens of microliters of } \\
\text { plasma needed }\end{array}$ \\
\hline Accuracy & $\begin{array}{l}\text { Capable of separation of structural-like NPs } \\
\text { followed by avoiding of cross-reaction }\end{array}$ & $\begin{array}{l}\text { Susceptible to cross-reaction with BNP } \\
\text { metabolites and proBNP }\end{array}$ \\
\hline Analytical efficiency & $\begin{array}{l}\text { Low: totally several hours spend on multistep } \\
\text { cleanup, LC separation and data interpretation }\end{array}$ & $\begin{array}{l}\text { High: usually automatic operated on } \\
\text { commercial platform (e.g. around } \\
20 \text { min per sample in AxSYM system) }\end{array}$ \\
\hline Sequence/impurity identification & Yes & No \\
\hline Traceability & $\begin{array}{l}\text { SI traceable when standard curves are plotted } \\
\text { by SI-traceable certified reference material }\end{array}$ & $\begin{array}{l}\text { Because capacity of antibody could not } \\
\text { be traced to SI unit, immune results } \\
\text { are not SI traceable }\end{array}$ \\
\hline Calibrator type & Amino acids or peptides reference material & Synthetic or recombinant BNP 1-32 \\
\hline
\end{tabular}

material for obtaining a metrologically traceable measurement value [55]. However, the development of a reference material is a complicated and rigorous scientific task. According to the data from the Joint Committee for Traceability in Laboratory Medicine, only 30 types of clinical proteins have been standardized to date [56]. Technologies such as amino acid analytical methods based on isotope dilution MS and quantitative nuclear magnetic resonance methods are commonly adopted for impurity analysis and mass balance quantification. Once the purity of the candidate material is verified, it can be used for plasma BNP reference material preparation or quantification. Then, manufacturers would adopt this material for device calibration, and it would be applied for clinical measurement. 
Currently, metrology institutes such as the Laboratory of the Government Chemist (LGC, UK) and the National Institute of Metrology (China) are focusing on this research. LGC has published works related to the development of the BNP reference quantitative MS method [25]. Once a BNP 1-32 purity reference material is developed, it can provide a standard value for instrument calibration. Then no matter which immunoassay platform was selected, the measurement results could be traced to a reference value at any place and in any time, improving the measurement consistency.

\section{Analytical methods}

\section{Cleanup}

Cleanup could improve the analytical sensitivity and maintain the molecular stability. A method for the rapid isolation of BNP from DPP-IV and amino- and carboxypeptidases is strongly needed for BNP 1-32 analysis. At present, a variety of commercial products are available for BNP purification. Hawkridge et al. [14] used a C8 SPE column and dual-antibody approach to purify BNP from plasma. They found that the highest percentage recovery was approximately $10 \%$, and recovery improved as the incubation time was reduced and the primary antibody concentration was increased. Although no greater purification was achieved by any antibody, Lewis et al. [17] also found that the matrix effects were alleviated when using a C18 SPE to treat human plasma. Andrews et al. [45] developed an online analytical platform that includes cleanup, digestion, separation and MS detection. The results indicated that such an integrated online analytical approach is suitable for the measurement of low-abundance proteins.

In Tables 2 and 3, as the capture antibody could also bind to the metabolites of BNP 1-32 and proBNP, these methods exhibited a low specificity. However, the subsequent coupling to LC and MS devices allowed these targets to be conveniently separated and detected based on their polarity and relative molar mass. An immunoassay approach cannot recognize such NPs as easily as LC-MS. Therefore, the development of a BNP 1-32 enrichment approach could further increase the detection sensitivity and might decrease the cross-reactions in immunoassays.

\section{Chemical antibody}

To avoid undesirable cross-reactions, the development of novel antibodies might be an effective solution. Thus, the

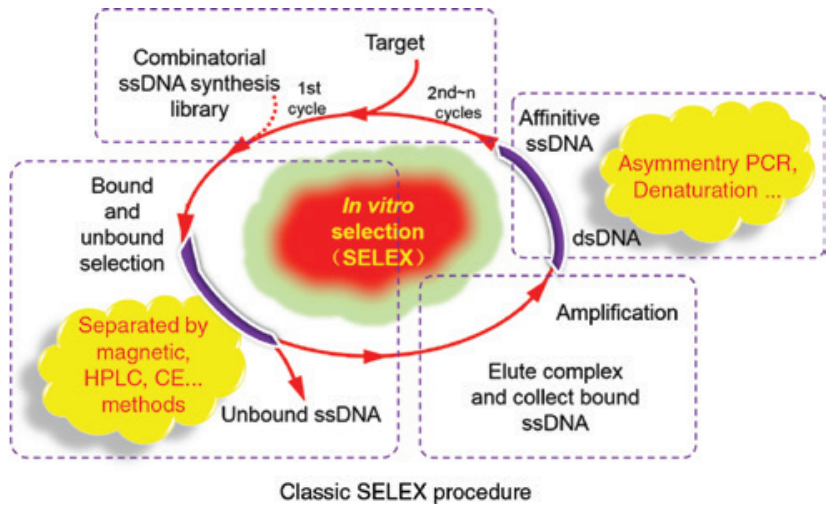

Figure 3: Principle of classic SELEX procedures.

preparation of amino-terminal antibodies is attractive. Here, another type of antibody, termed an aptamer, will be introduced.

Aptamers are single-stranded DNA or RNA oligonucleotides generated from an in vitro selection process termed SELEX, which stands for systematic evolution of ligands by exponential enrichment (Figure 3). This approach, independently proposed by three groups in 1990 [57-59], aims to develop aptamers that bind to their target with high selectivity and sensitivity owing to their three-dimensional structure. The high specific affinity of an aptamer to its target is thought to resemble that of chemical antibodies, with dissociation constants ranging from the nanomolar to picomolar levels [60]. Because of their high specific affinity, aptamers have broad applications that are undergoing rapid development in a variety of fields, such as disease diagnosis [61, 62], drug screening [63], bioseparation and bioanalysis [64-66] and RNA computing [67].

Hence, the selection of aptamers that specifically recognize the amino-terminal sequence might reduce cross-reaction. Once BNP 1-32 and the aptamer form a complex, the steric hindrance might block the common epitope, preventing the recognition of proBNP by this aptamer. Because of a lack of serine-proline or serine-proline-lysine-methionine sequences, truncated BNPs, such as BNP 3-32 and BNP 5-32, would also not be recognized. Although this research is ongoing in the authors' laboratory right now, previous inspiring results were reported by the Lewis group [17]. In brief, Lewis et al. [17] raised and utilized a homemade polyclonal antibody that recognizes BNP 1-13 to decrease the cross-reaction with proBNP.

In addition to specificity and sensitivity, aptamers are also low-cost and easily modified molecules. Aptamers can be produced easily by polymerase chain reaction and can be conveniently modified with functional groups 
or linkers. Based on these characteristics, an aptamerderived IVD reagent might be a promising tool for BNP 1-32 analysis without cross-reaction.

\section{Ionization efficiency}

\section{Supercharger}

One limitation of clinical MS application is that biomarkers usually have low or ultralow abundance in biological samples [25]. Although MS provides excellent sensitivity in select ion monitor mode or with an advanced mass analyzer, the cost is usually very high. Therefore, it is important to develop superchargers to increase the MS intensity $[68,69]$. Dimethyl sulfoxide (DMSO) is a supercharger well characterized by Hahne et al. [70]. They found that a low percentage of DMSO in LC solvents led to a strong enhancement of the electrospray ionization of peptides, improving the sensitivity of protein identification in bottom-up proteomics by up to tenfold. For BNP quantification, Torma et al. [25] also observed that DMSO could enhance the intensity of +6 and +7 charge ions of intact BNP after postcolumn addition.

\section{Alkylation}

Because there are two cysteines in intact BNP, their modification needs to be considered. Cysteine alkylation could increase the ionization efficiency and improve MS quantitation [71]. Shuford et al. [50] synthetized several types of hydrophobic alkylation reagents and used them for BNP alkylation. The isotope dilution MS results of BNP demonstrated that an adequate alkylation of BNP could lower the limit of detection and is especially suitable for the quantification of low-abundance proteins based on MS technology.

\section{Analytical devices}

\section{Ion mobility MS}

Synthetic peptides or proteins usually contain a variety of similarly structured impurities. For instance, according to the results of the international Key Comparison Project (CCQM K115), 81 types of peptide-related impurities existed in the synthetic human C-peptide sample, including six isomers [72]. Globally, pharmacopeia in different countries have also defined the threshold value of impurity for peptide drugs.
Before the invention of ion mobility MS (IM-MS), LC or CE was the common analytical approach for impurity separation. As a powerful complementary analytical approach to nuclear magnetic resonance and X-ray crystallography, IM-MS has more recently been widely applied in the field of structure characterization, with applications involving chemical warfare agents [73], supplements $[74,75]$, peptide measurement $[76,77]$, disease research $[78,79]$, drugs [80] and even protein complex conformation [81, 82]. SYNAPT HDMS is the first commercialized IM-MS device in the world and has the potential to analyze isomer ions because a drift tube is located at the front of the TOF analyzer. Briefly, the ions in the drift tube undergo physical collision with nitrogen or argon, and then the isomers with different cross-sections will arrive at the analyzer at distinct times.

Because mobility separation can be achieved in milliseconds, IM-MS is highly suitable for the quality control of synthetic BNP 1-32. For instance, Bros et al. [83] investigated the disulfide bond mismatch situation when using SYNAPT G2-S HDMS to analyze synthetic hepcidin, which possesses four pairs of disulfide bonds in the native structure. The sequence could also be identified by the ion fragmentation after IM separation. A rapid and reliable structural characterization method is beneficial for accurate quantification.

\section{Ionization source}

In recent years, some advanced electrospray ion sources have been commercialized and have demonstrated a robust ability to handle complicated matrix samples. Ambient mass spectrometry (AMS) [84] is undoubtedly a breakthrough in the MS field, and the most representative AMS techniques are desorption electrospray ionization (DESI) [85] (Figure 4) and direct analysis in real time [86]. Because of the absence of tedious sample preparation and time-consuming chromatographic separation, this technique provides great convenience for the rapid and straightforward analysis of target analytes in their native conditions [87], which is very attractive for the high-throughput screening and analysis of molecules with short half-lives, such as plasma BNP. Among all ion sources, spray-based ionization techniques, such as DESI and paper spray (PS), are the most popular techniques for blood or serum analysis in clinical chemistry.

Generally, in DESI, a fine spray of charged droplets bombards the surface of the sample, where the droplets pick up analyte molecules, ionize them in the gas phase and deliver them into the MS for further analysis. Wiseman 


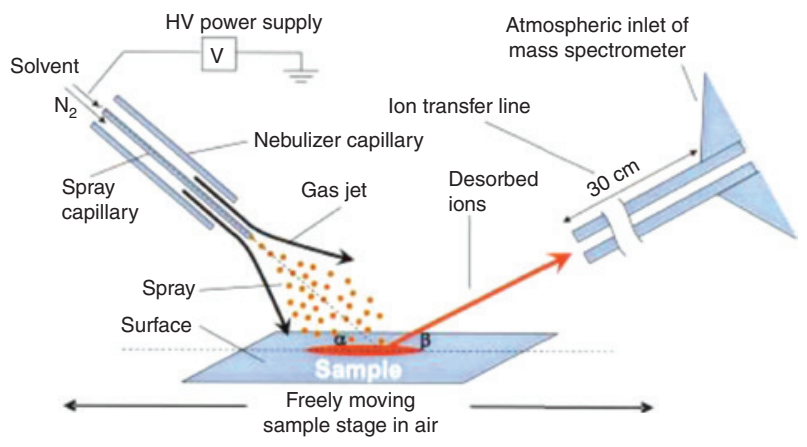

Figure 4: Scheme of DESI (reprinted from Bros et al. [83] with permission).

et al. [88] used DESI to quantitatively determine xenobiotics in whole blood samples without sample preparation or chromatography. The collected whole blood was spotted onto specialty paper and dried to obtain dried blood spots. In addition to small molecules, DESI can ionize proteins as large as $150 \mathrm{kDa}$, such as superoxide dismutase, enolase, hemoglobin, cytochrome $c$, gramicidin D and immunoglobulin $G$ [89]. In this study, liquid sample DESI was used directly for the analysis of solutions; therefore, blood could be directly ionized without spotting and drying.

In PS, the sample is loaded on triangular paper substrates with a sharp point, and a stable spray is formed with the application of spray solvent and a high electric field on wet paper [90]. The porous paper substrate plays three roles: sample collection, analyte separation and ionization. In contrast to DESI, the paper introduces chromatographic separation to decrease matrix effects, so PS showed better performance in complex mixture analysis. Surface modification of the paper can greatly enhance its capability as a separation medium, as illustrated by silica-coated paper [91], zirconia-coated paper [92] and silver nanoparticle-coated paper [93].

Ambient ion sources are highly convenient for sample analysis, but the lower ionization efficiency severely restricts their further application in ultratrace analyte determination. Obviously, the detection of BNP in blood is a challenging task, and there are no reports to date. Therefore, sample preparation strategies [94] have been developed to improve the practical utility of techniques for the detection of ultratrace analytes, including SPE [95], solid-phase microextraction [96] and immunoaffinity. Chen and Badu-Tawiah [97] built a PS-based immunoassay platform for large molecule detection, including malaria antigen and cancer antigen. High selectivity was achieved by antigen and antibody interaction, and high ionization efficiency was achieved by the use of cleavable ionic probes as a mass reporter. The reliability of results is strongly dependent on the internal standard; therefore, the development of a BNP reference material is essential for such advanced DESI analysis.

\section{Conclusions}

MS provides excellent selectivity, precision and accuracy in measurement, and the development of MS instrumentation and informatics tools has set the stage for protein analysis to emerge in the clinical laboratory [60, 98]. Because many NPs coexist in the circulation of HF patients, additional separation was commonly needed before MS profiling. Fortunately, in recent years, some technologies, such as IM-MS and DESI ionization, have provided direct analytical ability, which would reduce the complexity of clinical measurement.

In essence, the structural diversity of circulating NPs leads to overestimated immunoassay results. In addition, the lack of standardization capacity is the main reason for the poor harmonization of clinical measurement results. Both situations could introduce error into the measurement results; however, the approaches to resolution are distinct. The development of amino-terminal-specific recognition or detection ligands is an effective method for reducing cross-reactions. Meanwhile, research on SItraceable reference materials or reference measurement procedures will increase measurement consistency. In practice, however, the mentioned resolving approaches in this review might be helpful in the standardization of a specific BNP or an unprocessed proBNP measurement, but not suitable for the standardization of multiple BNP and proBNP measurement in clinical. Clinically relevant BNP is represented by a mixture of BNP-related peptides, and the analysis of such very heterogeneous analyte is a challenge for clinical researchers; therefore, although analytical technology has been improved rapidly in the current, there is still a long way for the standardization of measurement of BNP-related peptides.

Acknowledgments: The authors acknowledge financial support from the National Nature Science Foundation of China (21705144) and the National Key R\&D Program of China (2017YFF0205401).

Author contributions: All the authors have accepted responsibility for the entire content of this submitted manuscript and approved submission.

Research funding: This workwas supported by the National Nature Science Foundation of China (21705144) and the National Key R\&D Program of China (2017YFF0205401). 
Employment or leadership: None declared.

Honorarium: None declared.

Competing interests: The funding organization(s) played no role in the study design; in the collection, analysis and interpretation of data; in the writing of the report; or in the decision to submit the report for publication.

\section{References}

1. De Bold AJ, Borenstein HB, Veress AT, Sonnenberg H. A rapid and potent natriuretic response to intravenous injection of atrial myocardial extract in rats. Life Sci 1981;28:89-94.

2. De Bold AJ. Atrial natriuretic factor: a hormone produced by the heart. Science 1985;230:767-70.

3. Goetze JP. Biochemistry of pro-b-type natriuretic peptidederived peptides: the endocrine heart revisited. Clin Chem 2004;50:1503-10.

4. de Lemos JA, McGuire DK, Drazner MH. B-Type natriuretic peptide in cardiovascular disease. Lancet 2003;362: 316-22.

5. Liebetrau C, Gaede L, Dörr O, Blumenstein J, Rosenburg S, Hoffmann J, et al. Reference values and release kinetics of B-type natriuretic peptide signal peptide in patients with acute myocardial infarction. Clin Chem 2015;61:1532-9.

6. Levin ER, Gardner DG, Samson WK. Natriuretic peptides. N Engl J Med 1998;339:321-8.

7. Colucci WS, Elkayam U, Horton DP, Abraham WT, Bourge RC, Johnson $A D$, et al. Intravenous nesiritide, a natriuretic peptide, in the treatment of decompensated congestive heart failure. $\mathrm{N}$ Engl J Med 2000;343:246-53.

8. Januz JL. B-Type natriuretic peptide testing in the era of neprilysin inhibition: are the winds of change blowing? Clin Chem 2016;62:663-5.

9. Emdin M, Passino C, Prontera C, Fontana M, Poletti R, Gabutti A, et al. Comparison of brain natriuretic peptide (Bnp) and aminoterminal proBNP for early diagnosis of heart failure. Clin Chem 2007;53:1289-97.

10. Clerico A, Franzini M, Masotti S, Prontera C, Passino C. State of the art of immunoassay methods for B-type natriuretic peptides: an update. Crit Rev Clin Lab Sci 2014;52:56-69.

11. Ponikowski P, Voors AA, Anker SD, Bueno H, Cleland J, Coats A, et al. 2016 ESC guidelines for the diagnosis and treatment of acute and chronic heart failure: the task force for the diagnosis and treatment of acute and chronic heart failure of the European Society of Cardiology (ESC). Developed with the special contribution of the Heart Failure Association (HFA) of the ESC. Eur J Heart Fail 2016;18:891-975.

12. Cantinotti M, Clerico A, Murzi M, Vittorini S, Emdin M. Clinical relevance of measurement of brain natriuretic peptide and $\mathrm{N}$-terminal pro-brain natriuretic peptide in pediatric cardiology. Clin Chim Acta 2008;390:12-22.

13. Cantinotti M, Storti S, Parri MS, Murzi M, Clerico A. Reference values for plasma $B$-type natriuretic peptide in the first days of life. Clin Chem 2009;55:1438-40.

14. Hawkridge AM, Heublein DM, Bergen HR, Cataliotti A, Burnett JC, Muddiman DC, et al. Quantitative mass spectral evidence for the absence of circulating brain natriuretic peptide (BNP-32) in severe human heart failure. Proc Natl Acad Sci USA 2005;102:17442-7.

15. Niederkofler EE, Kiernan UA, O'Rear J, Menon S, Saghir S, Protter $A A$, et al. Detection of endogenous B-type natriuretic peptide at very low concentrations in patients with heart failure. Circ Heart Fail 2008;1:258-64.

16. Miller WL, Phelps MA, Wood CM, Schellenberger U, Le AV, Perichon R, et al. Comparison of mass spectrometry and clinical assay measurements of circulating fragments of B-type natriuretic peptide in patients with chronic heart failure. Circ Heart Fail 2011;4:355-60.

17. Lewis LK, Raudsepp SD, Yandle TG, Prickett TC, Richards AM. Development of a BNP1-32 immunoassay that does not crossreact with proBNP. Clin Chem 2017;63:1110-7.

18. Saenger AK, Rodriguez-Fraga O, Ler R, Ordonez-Llanos J, Jaffe AS, Goetze JP, et al. Specificity of B-type natriuretic peptide assays: cross-reactivity with different BNP, nt-proBNP, and proBNP peptides. Clin Chem 2017;63:351-8.

19. Clerico A, Zaninotto M, Prontera C, Giovannini S, Ndreu $\mathrm{R}$, Franzini M, et al. State of the Art of BNP and nt-proBNP immunoassays: the Cardioormocheck Study. Clin Chim Acta 2012;414:112-9.

20. Franzini M, Masotti S, Prontera C, Ripoli A, Passino C, Giovannini S, et al. Systematic differences between BNP immunoassays: comparison of methods using standard protocols and quality control materials. Clin Chim Acta 2013;424:287-91.

21. Xu-Cai YO, Wu Q. Molecular forms of natriuretic peptides in heart failure and their implications. Heart 2010;96:419-24.

22. Goetze JP. B-type natriuretic peptide: from posttranslational processing to clinical measurement. Clin Chem 2012;58:83-91.

23. Maalouf R, Bailey S. A review on B-type natriuretic peptide monitoring: assays and biosensors. Heart Fail Rev 2016;21:567-78.

24. Vasile VC, Jaffe AS. Natriuretic peptides and analytical barriers. Clin Chem 2017;63:50-8.

25. Torma AF, Groves K, Biesenbruch S, Mussell C, Reid A, Ellison S, et al. A candidate liquid chromatography mass spectrometry reference method for the quantification of the cardiac marker 1-32 B-type natriuretic peptide. Clin Chem Lab Med 2017;55:1397-406.

26. Cauliez B, Santos H, Bauer F, Basuyau JP, Nadolny A, Galpy G, et al. Cross-reactivity with endogenous proBNP from heart failure patients for three commercial BNP immunoassays. Clin Chim Acta 2012;413:337-8.

27. Luckenbill KN, Christenson RH, Jaffe AS, Mair J, Ordonezllanos J, Pagani F, et al. Cross-reactivity of BNP, nt-proBNP, and proBNP in commercial BNP and nt-proBNP assays: preliminary observations from the IFCC committee for standardization of markers of cardiac damage. Clin Chem 2008;54:619-21.

28. Ichiki T, Huntley BK, Burnett JC. Bnp molecular forms and processing by the cardiac serine protease corin. Adv Clin Chem 2013;61:1-31.

29. Yandle TG, Richards AM. B-type natriuretic peptide circulating forms: analytical and bioactivity issues. Clin Chim Acta 2015;448:195-205.

30. He XL, Dukkipati A, Garcia KC. Structural determinants of natriuretic peptide receptor specificity and degeneracy. J Mol Biol 2006;361:698-714. 
31. Koller KJ, Goeddel DV. Molecular biology of the natriuretic peptides and their receptors. Circulation 1992;86:1081-8.

32. Zois NE, Bartels ED, Hunter I, Kousholt BS, Olsen LH, Goetze JP, et al. Natriuretic peptides in cardiometabolic regulation and disease. Nat Rev Cardiol 2014;11:403-12.

33. Semenov AG, Katrukha AG. Different susceptibility of B-type natriuretic peptide (BNP) and BNP precursor (proBNP) to cleavage by neprilysin: the $\mathrm{N}$-terminal part does matter. Clin Chem 2016;62:617-22.

34. Brandt I, Lambeir AM, Ketelslegers JM, Vanderheyden M, Scharpé S, De Meester I. Dipeptidyl-peptidase IV converts intact B-type natriuretic peptide into its des-SerPro form. Clin Chem 2006;52:82-7.

35. Tamm NN, Seferian KR, Semenov AG, Mukharyamova KS, Koshkina EV, Krasnoselsky MI, et al. Novel immunoassay for quantification of brain natriuretic peptide and its precursor in human blood. Clin Chem 2008;54:1511-8.

36. Holmes SJ, Espiner EA, Richards AM, Yandle TG, Frampton C. Renal, endocrine, and hemodynamic effects of human brain natriuretic peptide in normal man. J Clin Endocrinol Metab 1993;76:91-6.

37. Rutten JH, Mattace-Raso FU, Steyerberg EW, Lindemans J, Hofman A, Wieberdink RG, et al. Amino-terminal pro-b-type natriuretic peptide improves cardiovascular and cerebrovascular risk prediction in the population: the rotterdam study. Hypertension 2010;55:785-91.

38. Gundry RL, Van Eyk JE. Unraveling the complexity of circulating forms of brain natriuretic peptide. Clin Chem 2007;53:1181-2.

39. Seferian KR, Tamm NN, Semenov AG, Mukharyamova KS, Tolstaya AA, Koshkina EV, et al. The brain natriuretic peptide (BNP) precursor is the major immunoreactive form of BNP in patients with heart failure. Clin Chem 2007;53:866-73.

40. Apple FS, Panteghini M, Ravkilde J, Mair J, Wu AH, Tate J, et al. Quality specifications for B-type natriuretic peptide assays. Clin Chem 2005;51:486-93.

41. Liang F, O'Rear J, Schellenberger U, Tai L, Lasecki M, Schreiner G, et al. Evidence for functional heterogeneity of circulating B-type natriuretic peptide. J Am Coll Cardiol 2007;49:1071-8.

42. Heublein DM, Huntley BK, Boerrigter G, Cataliotti A, Sandberg SM, Redfield MM, et al. Immunoreactivity and guanosine 3', $5^{\prime}$-cyclic monophosphate activating actions of various molecular forms of human B-type natriuretic peptide. Hypertension 2007;49:1114-9.

43. Suzuki T, Israr MZ, Heaney LM, Takaoka M, Squire IB, Ng LL. Prognostic role of molecular forms of B-type natriuretic peptide in acute heart failure. Clin Chem 2017;63:880-6.

44. Siriwardena M, Kleffmann T, Ruygrok P, Cameron V, Yandle T, Nicholls $M$, et al. B-type natriuretic peptide signal peptide circulates in human blood: evaluation as a potential biomarker of cardiac ischemia. Circulation 2010;122:255-64.

45. Andrews GL, Shuford CM, Burnett JC, Hawkridge AM, Muddiman DC. Coupling of a vented column with splitless nanoRPLC-ESI-MS for the improved separation and detection of brain natriuretic peptide-32 and its proteolytic peptides. J Chromatogr B 2009;10:948-54.

46. Johnson KR, Hoagland TM, Olson KR. Endogenous vascular synthesis of $\mathrm{B}$-type and $\mathrm{C}$-type natriuretic peptides in the rainbow trout. J Exp Biol 2011;214:2709-17.

47. Fujimoto H, Suzuki T, Aizawa K, Sawaki D, Ishida J, Ando J, et al. Processed B-type natriuretic peptide is a biomarker of postin- terventional restenosis in ischemic heart disease. Clin Chem 2013;59:1330-7.

48. Chappell DL, Lee AY, Bernstein HS, Lassman ME, Laterza OF. Development and validation of an IA-LC/MS method to quantitate active and total B-type natriuretic peptide in human plasma. Bioanalysis 2016;8:2341-9.

49. Vatansever B, Lahrichi SL, Thiocone A, Salluce N, Mathieu M, Grouzmann E, et al. Comparison between a linear ion trap and a triple quadruple MS in the sensitive detection of large peptides at femtomole amounts on column. J Sep Sci 2010;33:2478-88.

50. Shuford CM, Comins DL, Whitten JL, Burnett JC, Muddiman DC. Improving limits of detection for B-type natriuretic peptide using PC-IDMS: an application of the aliphat strategy. Analyst 2010;135:36-41.

51. Zhang S, Raedschelders K, Santos M, Van Eyk JE. Profiling B-type natriuretic peptide cleavage peptidoforms in human plasma by capillary electrophoresis with electrospray ionization mass spectrometry. J Proteome Res 2017;16:4515-22.

52. Kullo IJ, Cooper LT. Early identification of cardiovascular risk using genomics and proteomics. Nat Rev Cardiol 2010;7:309-17.

53. Wright I, Van Eyk JE. A roadmap to successful clinical proteomics. Clin Chem 2017;63:245-7.

54. Lehmann S, Brede C, Lescuyer P, Cocho JA, Vialaret J, Bros P, et al. Clinical mass spectrometry proteomics (CMSP) for medical laboratory: what does the future hold? Clin Chim Acta 2017;467:51-8.

55. ISO 17511:2003. In vitro diagnostic medical devices measurement of quantities in samples of biological origin metrological traceability of values assigned to calibrators and control materials.

56. The Joint Committee for Traceability in Laboratory Medicine (JCTLM). https://www.bipm.org/jctlm/.

57. Ellington AD, Szostak JW. In vitro selection of RNA molecules that bind specific ligands. Nature 1990;346:818-22.

58. Tuerk C, Gold L. Systematic evolution of ligands by exponential enrichment: RNA ligands to bacteriophage T4 DNA polymerase. Science 1990;249:505-10.

59. Robertson DL, Joyce GF. Selection in vitro of an RNA enzyme that specifically cleaves single-stranded DNA. Nature 1990;344: 467-8.

60. Iliuk AB, Hu L, Tao WA. Aptamer in bioanalytical applications. Anal Chem 2011;83:4440-52.

61. Nimjee SM, Rusconi CP, Sullenger BA. Aptamers: an emerging class of therapeutics. Annu Rev Med 2005;56:555-83.

62. Gubala V, Harris LF, Ricco AJ, Tan MX, Williams DE. Point of care diagnostics: status and future. Anal Chem 2012;84:487-515.

63. Missailidis S, Hardy A. Aptamers as inhibitors of target proteins. Expert Opin Ther Pat 2009;19:1073-82.

64. Shastri A, Mcgregor LM, Liu Y, Harris V, Nan H, Mujica M, et al. An aptamer-functionalized chemomechanically modulated biomolecule catch-and-release system. Nat Chem 2015;7:447-54.

65. Mairal T, Ozalp VC, Lozano Sánchez P, Mir M, Katakis I, O'Sullivan C. Aptamers: molecular tools for analytical applications. Anal Bioanal Chem 2008;390:989-1007.

66. Smith JC, Lambert JP, Elisma F, Figeys D. Proteomics in 2005/2006: developments, applications and challenges. Anal Chem 2007;79:4325-43.

67. Shapiro E, Gil B. RNA computing in a living cell. Science 2008;322:387-8. 
68. Sterling HJ, Williams ER. Origin of supercharging in electrospray ionization of noncovalent complexes from aqueous solution.

J Am Soc Mass Spectrom 2009;20:1933-43.

69. Miladinović SM, Fornelli L, Lu Y, Piech KM, Girault HH, Tsybin YO. In-spray supercharging of peptides and proteins in electrospray ionization mass spectrometry. Anal Chem 2012;84:4647-51.

70. Hahne H, Pachl F, Ruprecht B, Maier SK, Klaeger S, Helm D. Dmso enhances electrospray response, boosting sensitivity of proteomic experiments. Nat Methods 2013;10:989-91.

71. Mirzaei H, Regnier F. Enhancing electrospray ionization efficiency of peptides by derivatization. Anal Chem 2006;78:4175-83.

72. Josephs RD, Li M, Song D, Westwood S, Stoppacher N, Daireaux A, et al. Key comparison study on peptide purity-synthetic human C-peptide. Metrologia 2017;54(Technical Supplement, 1A):08007.

73. D’Agostino PA, Chenier CL. Desorption electrospray ionization mass spectrometric analysis of organophosphorus chemical warfare agents using ion mobility and tandem mass spectrometry. Rapid Commun Mass Spectrom 2010;24:1617-24.

74. Dong L, Shion H, Davis RG, Terry-Penak B, Castro-Perez J, van Breemen RB. Collision cross-section determination and tandem mass spectrometric analysis of isomeric carotenoids using electrospray ion mobility time-of-flight mass spectrometry. Anal Chem 2010;82:9014-21.

75. Xiao P, Li HM, Li M, Song D, Li X, Dai X, et al. Structural characterization and thermally induced isomerization investigation of cis- and trans-vitamin $\mathrm{K}_{1}$ using ion mobility mass spectrometry. Anal Methods 2015;7:8432-8.

76. Lee S, Li Z, Valentine SJ, Zucker SM, Webber N, Reilly JP, et al. Extracted fragment ion mobility distributions: a new method for complex mixture analysis. Int J Mass Spectrom 2012;309:154-60.

77. Thalassinos K, Grabenauer M, Slade SE, Hilton GR, Bowers MT, Scrivens JH. Characterization of phosphorylated peptides using traveling wave-based and drift cell ion mobility mass spectrometry. Anal Chem 2009;81:248-54.

78. Kłoniecki M, Jabłonowska A, Poznański J, Langridge J, Hughes C, Campuzano I, et al. Ion mobility separation coupled with MS detects two structural states of Alzheimer's disease A $\beta 1-40$ peptide oligomers. J Mol Biol 2011;407:110-24.

79. Williams JP, Bugarcic T, Habtemariam A, Giles K, Campuzano I, Rodger PM, et al. Isomer separation and gas-phase configurations of organoruthenium anticancer complexes: ion mobility mass spectrometry and modeling. J Am Soc Mass Spectrom 2009;20:1119-22.

80. Cuyckens F, Wassvik C, Mortishire-Smith RJ, Tresadern G, Campuzano I, Claereboudt J. Product ion mobility as a promising tool for assignment of positional isomers of drug metabolites. Rapid Commun Mass Spectrom 2011;25:3497-503.

81. Lane LA, Fernández-Tornero C, Zhou M, Morgner N, Ptchelkine D, Steuerwald U, et al. Mass spectrometry reveals stable modules in holo and apo RNA polymerases I and III. Structure 2011;19:90-100.

82. Hall Z, Politis A, Robinson CV. Structural modeling of heteromeric protein complexes from disassembly pathways and ion mobility-mass spectrometry. Structure 2012;20:1596-609.
83. Bros P, Josephs RD, Stoppacher N, Cazals G, Lehmann S, Hirtz C, et al. Impurity determination for hepcidin by liquid chromatography-high resolution and ion mobility mass spectrometry for the value assignment of candidate primary calibrators. Anal BioAnal Chem 2017;409:2559-67.

84. Cooks RG, Ouyang Z, Takats Z, Wiseman JM. Detection technologies. Ambient mass spectrometry. Science 2006;311:1566-70.

85. Takáts Z, Wiseman JM, Gologan B, Cooks RG. Mass spectrometry sampling under ambient conditions with desorption electrospray ionization. Science 2004;306:471-3.

86. Li X, Wang X, Li L, Bai Y, Liu H. Direct analysis in real time mass spectrometry: a powerful tool for fast analysis. Mass Spectrom Lett 2015;6:1-6.

87. Zhang J, Yu W, Suliburk J, Eberlin LS. Will ambient ionization mass spectrometry become an integral technology in the operating room of the future? Clin Chem 2016;62:1172-4.

88. Wiseman JM, Evans CA, Bowen CL, Kennedy JH. Direct analysis of dried blood spots utilizing desorption electrospray ionization (DSEl) mass spectrometry. Analyst 2010;135:720-5.

89. Ferguson CN, Benchaar SA, Miao Z, Loo JA, Chen H. Direct ionization of large proteins and protein complexes by desorption electrospray ionization-mass spectrometry. Anal Chem 2011;83:6468-73.

90. Wang H, Liu J, Cooks RG, Ouyang Z. Paper spray for direct analysis of complex mixtures using mass spectrometry. Angew Chem Int Ed Engl 2010;49:877-80.

91. Zhang Z, Xu W, Manicke NE, Cooks RG, Ouyang Z. Silica coated paper substrate for paper-spray analysis of therapeutic drugs in dried blood spots. Anal Chem 2012;84:931-8.

92. Zheng Y, Wang Q, Wang X, Chen Y, Wang X, Zhang X, et al. Development and application of zirconia coated paper substrate for high sensitivity analysis of therapeutic drugs in dried blood spots. Anal Chem 2016;88:7005-13.

93. Fedick PW, Bills BJ, Manicke NE, Cooks RG. Forensic sampling and analysis from a single substrate: surface-enhanced raman spectroscopy followed by paper spray mass spectrometry. Anal Chem 2017;89:10973-9.

94. Li X, Ma W, Li H, Ai W, Bai Y, Liu H. Sampling and analyte enrichment strategies for ambient mass spectrometry. Anal BioAnal Chem 2018;41:715-24.

95. Li X, Li Z, Wang X, Nie H, Zhang Y, Bai Y, et al. Monolith dip-it: a bifunctional device for improving the sensitivity of direct analysis in real time mass spectrometry. Analyst 2016;141: 4947-52.

96. Fang L, Deng J, Yang Y, Wang X, Chen B, Liu H, et al. Coupling solid-phase microextraction with ambient mass spectrometry: strategies and applications. Trends Anal Chem 2016;85:61-72.

97. Chen S, Wan Q, Badu-Tawiah AK. Mass spectrometry for paperbased immunoassays: toward on-demand diagnosis. J Am Chem Soc 2016;138:6356-9.

98. Bystrom CE. The analysis of native proteins and peptides in the clinical lab using mass spectrometry. Clin Lab Med 2011;31: 397-405. 